\title{
Deconstructing the terrible gift of postcolonial African lives: An intertextual reading of Martin Egblewogbe's Mr. Happy and the Hammer of God \& Other Stories.
}

\author{
Prince Kwame Adika \\ Lecturer \\ Department of English \\ University of Ghana, Legon, Ghana \\ Email:pkadika@ug.edu.gh
}

Submitted: December 21, 2020 / Accepted: May 14, 2021/ Published: August 27, 2021

\begin{abstract}
This paper situates Martin Egblewogbe's short story collection Mr. Happy and the Hammer of God \& Other Stories (2008) within intertextual discourses as they relate to the tri-generational canon of Ghanaian, and by extension, African literature. It argues against the easy temptation of reading the work via uncontextualized metaphysical or existentialist paradigms, or what Wole Soyinka (1976) refers to as the undifferentiated mono-lenses of "universal humanoid abstractions," and instead situates it within the Ghanaian tradition by pointing out the collection's filiation to the specific trope of madness-as-a subversive-performance-of-resilience against the oppressive socio-political status quo in that tradition. The paper excavates the works of first generation postcolonial Ghanaian authors such as Armah, Awoonor and Aidoo, and reads Egblewogbe's relatively recent debut oeuvre against them in a grounded epistemic manoeuvre that fractures assumptions about the work's uniqueness and places it in on-going trans-generational dialogic exchanges about how to negotiate the fractious crucible that is postcolonial Ghanaian experience.
\end{abstract}

Keywords: post-colonial, Ghanaian tradition, intertextuality, trigenerational, resilience 


\section{Introduction}

Although general intertextual poetics has been employed as a framework to study postcolonial African literature in the scholarship of Soyinka (1976), Jeyifo (1988) Anyidoho (2003), Ojaide (2009), Ogede (2011), and others, there is a remarkable lack of specific emphasis on the dynamic of transgenerational intertextuality within the body of postcolonial African literature, especially given the scholarly consensus that postcolonial African literature as an evolving tradition is at least three generations old, and the plausible hypothesis that this evolution must hinge to a large extent on cross-generational dialogism. In this essay, I shall attempt to fill some of that gap by reading the work of third generation Ghanaian prose fiction writer, Martin Egblewogbe against two earlier novels by first generation postcolonial Ghanaian authors, Ayi Kwei Armah and Kofi Awoonor, and in the process, show how Egblewogbe's navigation of the complex realities of postcolonial space, identity and personhood in $21^{\text {st }}$ century Ghana re-inscribes some of the foundational tropes of postcolonial Ghanaian literature as first adumbrated by the leading writers of the immediate post-independence era.

I propose in this paper to analyse Martin Egblewogbe's first collection of short stories via a transgenerational intertextual epistemic paradigm that situates the work within a larger Ghanaian literary tradition that predates the independence era but comes into its own in the aftermath of political independence circa 1957 and therefore, fits into the three-generations old postcolonial frame of reference. More precisely, I shall read Egblewogbe's Mr. Happy and the Hammer of God \& Other Stories (2008) against Ayi Kwei Armah's Fragments (1969) and Kofi Awoonor's This Earth, My Brother (1971), and via that reading, attempt to show how the younger author's work re-inscribes the older texts of the postcolonial Ghanaian canon in remarkable ways even as it channels a subversive $21^{\text {st }}$ century riposte to the order of things. 


\section{Three generations of postcolonial African literary dialogism}

While it is a relatively young literary tradition compared with others, it is still useful to recognize right from the outset that the tradition of postcolonial African literature which Ghanaian literature is a part of is far past the infant years of mimicry and often uneven attempts at subaltern response to the narratives of Centre as captured by Currey (2008, pp.1-24) and others. While recognising a multiplicity of histories and local conditions influencing aesthetic choices and thematic concerns, Gikandi (2008), Ojaide (2009, 2015), and other literary genealogists have mapped at least three generations of creative writers working within the tradition of postcolonial African literature from the 1960s to the present moment. Across those three generations, Africa's creative writers have been occupied by concerns as diverse as didactics, ideological interpellation, national identity definition and affirmation, doubts about and vigorous critiques of the nascent project of the postcolonial nation-state, and outright renunciation of the same project amidst pronounced failures and disappointments (Achebe, 1989; Booker, 1998; Larbi Korang, 2004; Awoonor, 2006; Gikandi, 2008; Irele, 2009; Yitah, 2017).

The output of the first generation roughly coincides with the 1960s and 1970s and encompasses the work of such writers as Bernard Dadie, Chinua Achebe, Sembene Ousmane, Christopher Okigbo, Kofi Awoonor, Ngugi wa Thiong'O, and Ama Ata Aidoo; a generation known for pioneering revisions of Eurocentric narratives of African personhood and cheerleading a nationalist discourse in the aftermath of colonialism even if, already in some of their writings, signs of despair and disappointment begin to show. The second generation, prominent in the 1980s and 1990s, comprises the likes of Kofi Anyidoho, Niyi Osundare, Jack Mapanje, Femi Osofisan, Nuruddin Farah, and Tanure Ojaide who focus their attentions on the failed project of the nation state and the betrayal of African peoples' aspirations by an elite that has lost its way (Ojaide, 2009, pp.2-18). This second generation carries the burden of Afro-pessimism at its 
heaviest, and they are followed by a third generation that consists of the likes of Benjamin Kwakye, Chimamanda Ngozi Adichie, Sefi Atta, Vonani Bila, and others who have become prominent since the onset of the 2000s. Coming of age at the turn of the millennium, a number of these third-generation writers are often urban and cosmopolitan in outlook and have broadened the scope of their narratives to cover issues such as gender, sex, and race and the intersectional praxes of these, while often revising the concerns of earlier writers within the postcolonial African canon (Selasie, 2005; Andrade, 2011).

While a taxonomy of postcolonial African literature(s) such as the one described above recognizes overlaps across generations and stresses writers in vogue over a period rather than suggest uniform cut-off points for the creative output of individual writers within generations, it nevertheless provides a useful entry point for discussions of canonicity and an evolving tradition of postcolonial African literature, and the potential dialogisms between various authors and their works across generations. It also clearly helps in delineating phasebound works that are clearly marked by concerns associated with one generation as opposed to the other, and thus provide useful material for comparative, transgenerational studies. That potential for interesting research material notwithstanding, the scholarly record disappoints when it comes to cross-generational intertextual studies focused on interactions between the texts of these writers from across generations. The important studies of general intertextual poetics in the African literary context such as Soyinka (1976), Jeyifo (1988), Anyidoho (2003), Kehinde (2003), Ogede (2011), Mavengano and Hove (2019), while useful, have tended to focus less on the specific dynamic of generations of postcolonial African literary texts in conversation, and even rare exceptions such as Andrade (2011, pp. 91-101) only seem to emphasize the gap in scholarship especially given the widely recognised importance of intertextual exchanges in the evolution of the creative arts. 


\section{Intertextuality and literary traditions: A brief note}

Although it is generally accepted that the term was first coined by the Bulgarian-French philosopher, Julia Kristeva in 1966 , the concept of intertextuality precedes that coinage by decades, if not centuries. Kristeva herself invokes intertextuality because, as she puts it:

Any text is constructed as a mosaic of quotations, any text is the absorption and transformation of another... In the space of a given text, several utterances, taken from other texts, intersect and neutralize one another (qtd in Clayton and Rothstein, 1991, p.29)

Zengin (2016, p. 1) reminds us that "the formulations of such theorists as Ferdinand de Saussure, Mikhail Bakhtin and Roland Barthes provide the introduction of intertextuality as a critical theory and an approach to texts before the term was coined by Kristeva." Similar arguments could be made of T.S. Eliot's now famous reference to intra-traditional dialogues as the bases upon which talents of individual artists develop or Harold Bloom's more adversarial vision of cross-generational artists in dialogue via the paradoxically renewing force of anxious influence (Bloom, 1994, pp. 15-39). Across the broader sweep of scholarly perspectives on intertextuality, the conclusion seems to be that we cannot understand creative works in a vacuum, and that texts only make sense when read against other texts, or as Eliot puts it succinctly in his seminal essay on the subject:

No poet, no artist of any art, has his complete meaning alone. His significance, his appreciation is the appreciation of his relation to the dead poets and artists. You cannot value him alone; you must set him, for contrast and comparison, among the dead. I mean this as a principle of aesthetic, not merely historical criticism (Eliot, 2001, p.1093) 
Eliot refers to the interplay of tradition and individual talent, the living dialogue between authors from various generations that, he argues, is the lifeblood that invigorates all traditions. Similarly, Anyidoho (2004) refers to an eternal dialogue of backness and frontness that is complementary to the growth of artistic traditions and thus emphasizes intertextuality as key to the integrity of all artistic enterprise. Anyidoho particularly emphasizes the influence of oral aesthetics on contemporary African writing, citing notable examples from first generation postcolonial African writers who attained worldwide recognition by engaging in dialogues with ancestral artists. Further, Soyinka, in the influential tome, Myth, Literature and the African World, stresses the intertextual framework of African art and aesthetics by highlighting how the African world, like any other world, exists in a comprehensive network of myth, history and mores that inform and re-energize generations of self-apprehending artists who are nourished by that cosmic totality via a dialogic co-existence with it (1976: xi-xii).

\section{The Ghanaian literary tradition: The road to the Afro- pessimist present}

To understand the workings of the intertextual within Ghanaian literary discourse, one needs to configure a canonical framework, a tradition of recognised texts proceeding out of a clearly recognised and expert-sanctioned textual culture which also doubles as an on-going conversation about metaphors of being and self-definition (Anyidoho, 2000, p. 1-22). Since this essay's larger goal is to situate Martin Egblewogbe in a dialogue dating back to previously recognised authors within the larger Ghanaian tradition, it is only appropriate that we historicize that tradition, even if only briefly. Angmor (2003) has argued that we need to understand the Ghanaian literary tradition in English - and hence the one created in the aftermath of the colonial Encounter - as dating back at least to the publication of J.E. Casely Hayford's Ethiopia Unbound in 1911, and Anyidoho 
(2000, p. 7) has suggested that we take this process further back to $1886-1887$ when A. Native's Marita was published. What Anyidoho, Angmor, and others like Larbi Korang (2004) have established beyond doubt is that post-independence Ghanaian literature has its antecedents in the pioneer writers of the late $19^{\text {th }}$ and early $20^{\text {th }}$ centuries; colonial-era pathfinders whose names include Kobena Sekyi, F.K. Fiawoo, R.E. Obeng, Gladys Casely Hayford, and Michael Dei Anang, and whose works often charted a distinctly nationalist course even as their authors were actively involved in the anticolonial politics of the first half of the $20^{\text {th }}$ century while the land mass that was to become Ghana was still known as the Gold Coast. Following these pioneer writers are the works of the first generation of post-independence Ghanaian writers such as Efua Sutherland, J.C. de Graft, Ayi Kwei Armah, Kofi Awoonor, Armah Ata Aidoo; second generation authors like Kofi Anyidoho, Kobena Eyi Acquah, Atukwei Okai, Mohammed Ben Abdallah; and third generation writers such as Benjamin Kwakye, Efo Kodjo Mawugbe, Amma Darko and Mohammed Naseehu Ali.

Throughout its evolution, the Ghanaian literary tradition has followed a course not dissimilar to contemporary trends in Ghanaian politics and social life. The dreamy sequences of nationalist programmes and attempts at cultural and political self-assertion that we find in works of the pioneer Gold Coast writers are climaxed in Kwame Nkrumah's overtly celebratory autobiography, Ghana: The Autobiography of Kwame Nkrumah (1957), but that moment of triumph is immediately eclipsed by a sudden shift in tone from the joyous project of engineering the postcolonial society to the gloomy aftermath of independence and the failed promises attendant to it. Ayi Kwei Armah, writing just a decade after the publication of Nkrumah's Autobiography, gives vent to this change in outlook by calling his debut novel The Beautyful Ones Are Not Yet Born (1967). Elsewhere on the continent, the disappointments engendered by the onset of the postcolonial epoch are marked by depressing titles such as 
Oginga Odinga's Not Yet Uhuru, Chinua Achebe's No Longer at Ease and Wole Soyinka's The Man Died as a general strain of what has been aptly referred to as Afro-pessimism by the likes of Hartman (2003), Sexton (2016), and Nsele (2020) took over the discursive landscape of the continent.

Two years after the publication of The Beautyful Ones, Armah published the even more Afro-pessimistic novel, Fragments (1969), only to be followed almost immediately by Kofi Awoonor's This Earth, My Brother (1972). The general landscapes evoked by these two postcolonial Ghanaian works are remarkable for their portrayal of metaphorical (and literal) filth and a general atmosphere of existence sans hope and purpose, one in which the only refuge for the sensitive soul is madness. Armah and Awoonor's fictional worlds in Fragments and This Earth, are generally dominated by existential ennui that, as some scholars have noted, may apply universally in places beyond Africa where similar conditions apply, but these narratives also speak of worlds that are specifically circumscribed by the spatiolinear dynamics of the infant postcolonial African nation-state and its peculiar disappointments. The gloomy literary landscapes we find in the two works are only matched by the experiences of the characters in the works, especially what they experience in their minds. Said differently, one of the most obvious traits of the two early works is that they project social landscapes inundated with corruption and debilitating stasis, ones that in turn influence the mindscapes of characters with devastating consequences.

In Fragments, the effects of this state of violence reduce the leading character and others like him to blindly groping victims of pulverising postcolonial state, individuals whose shattered psyches mirror the zombie intentions of the postcolonial state. These victims could only muster "victim anger" and the impotent shame that knows that it can do nothing. Earlier in The Beautyful Ones, Armah's debut novel, we are told of similar victims who "found it impossible to survive the destruction of the world they 
had carried away with them in their departing heads and so they simply went mad..." (p. 65). The trend is further exposed in Fragments. Onipa Baako is a more elaborated upon example of the victim of the malodorous society and its debilitating effects on the individual psyche. He, like a helpless child brought to the altar of a conscienceless, corrupt society, is:

The sacrifice they killed, to satisfy perhaps a new god they have found much like the one that began the same long destruction of our people when our elders first...split their own seed and raised half against half, part selling part to hard-eyed buyers from beyond the horizon, breaking, buying, selling, gaining, spending till the last of our men sells the last woman to any passing white buyer and himself waits to be destroyed by this great haste to consume things we have taken no care nor trouble to produce...(p. 283)

One senses in this passage a pattern of self-inflicted chaos that dates back to multiple generations, and which has only exacerbated over time as successive generations of selfish exploiters destroy in order to satiate their interests. The oppressive soulnessness that dominates this society drives Baako and other conscious ones in Fragments into the limbo of madness as they give up on their dreams to effect positive change.

Similarly, Awoonor's Amaamu in This Earth, My Brother is the disappointed scion of a liberation struggle gone awry and a newly minted specimen of the postcolonial fall. His name literally means the man has fallen and is symbolic of the fall of a just postcolonial society in Ghana. The palette of violence against which Amaamu lives his life in the new, postcolonial Ghana that so discourages him that it makes him take refuge in the poetry of esoteric self-talk and the quixotic comfort of the catatonic smile which refuses to notice anyone or anything ( $p$. 180). This is after he realises belatedly that despite his best efforts to chart a new course of progress, "the reconciliation of the Bull 
and the Man cannot be achieved now, for there are a million ancestral crimes that must be atoned for" (p. 161). He too, like Baako, thus takes refuge in the dark reverie of disengaged consciousness, the fragmented after-course of a life lived in the maelstrom of all things devastating. Baako and Amaamu's literary near contemporary, Zirigu, in Ama Ata Aidoo's "For Whom Things Did Not Change" (1970) presents an eloquent summary of this postcolonial nightmare:

I have thought and thought about it. I have never understood why. For a long time, I was drinking. I wanted to go away. I wanted to kill somebody. Any time I went to the office in town to get my pay and give my reports about the place, I felt like spitting into their eyes... Now the anger is gone, and I stay here. My young Master, what does "Independence" mean?" (p. 34)

Baako, Amaamu, and Zirigu, and others like them occupy a world that is turned upside down by riggers who seem all powerful in their ubiquity and invincibility. Out of these three men and others like them in the canon of postcolonial Ghanaian literature we may create a composite man, or we may yet stick to them in their individual particulars. The result would be practically the same: the features of futile struggle against a reactionary social order, of hopeless compulsion against retrogressive inertia, of ultimate surrender to despairing madness in the face of overwhelming odds. I suggest that they represent a type in the Ghanaian literary topos, a sort of ur-persona of the postcolonial moment that has been revisited by various Ghanaian authors since the publications of Fragments and This Earth, My Brother but are taken up in a more comprehensive intertextual dialogue in Martin Egblewogbe's Mr. Happy and the Hammer of God. 
Surviving post-happiness: Madness as a mode of survival in Mr. Happy and the Hammer of God \& Other Stories

Madness as a mode of survival and a subversive response to the stark realities of postcolonial African lived experiences has been brilliantly explored in the work of Veit-Wild (2008) and could well be added to what Anyidoho (2000, p. 3) calls "the defining metaphors of the Ghanaian cultural landscape." It certainly drives works as diverse as Ayi Kwei Armah's The Beautyful Ones and Fragments, Awoonor's This Earth, My Brother, Efua Sutherland's Edufa, Ama Ata Aidoo's Anowa, and Mohammed Naseehu Ali's The Prophet of Zongo Street. It is a fulcruming device for the stories of the many misfits of the brave new postcolonial Ghanaian society whose realities the various authors seek to chronicle. The continuum ranging from initial hopes of happiness to the existential nadir of madness retraces itself in work after work in the Ghanaian canon as harvests of joyous dreams become nightmares of mind-boggling doom for the system-declared denizenry of the postcolonial epoch. The iteration of the conscientious individual gone mad in successive works points to the problematic reality of a society that cannot sustain the dreams of its members, but it also emphasizes an intertextual dialogic dynamic that should not be taken for granted.

The general feedback to Egblewogbe's Mr. Happy strongly suggests that critics see the element of existential unease and metaphysical wandering as core to its message. Nana Fredua-Agyeman (2012, np), for instance, stresses a narrative strategy that fuses "the mind and the metaphysical with such a passion and intensity that many other storytellers lack" while Ama Ata Aidoo reads in its urban narrative landscape the tensions of a work that is both African and "not particularly African, [one that has] much of the unsettling elements that plague contemporary humanity" (2012, np). Anyidoho is drawn more to the stylistic finesse, "the often-crisp sentences, carefully balanced...the narrative voice [that] speaks abruptly 
of a world that unsettles your thoughts, a world that fascinates and startles" (2002, np). Hidden within all these readings is the unvoiced and yet strongly hinted at subtext that Mr. Happy's power to surprise and unsettle comes from its appropriation of the startlingly unnerving and paradoxical consciousness of a madman as a mediating device to render the story of twentyfirst century urban Ghanaian lives. In other words, Mr. Happy crystallizes madness as a defining metaphor through which the larger story of postcolonial Ghanaian existence is narrated. In this appropriation of madness as a narrative trope, the work recalls earlier illustrious Ghanaian works driven by the trope of madness in the aftermath of postcolonial disappointment and the disorienting effects of a social order founded on institutionalised chaos.

Sibanda (2016) notes both this ancestral connection to earlier texts, and unorthodox narrative techniques in $M r$. Happy when he points out that the text is marked by:

...an existential angst which is signified in an Armahesque nameless, faceless manwhose world has eroded and effaced all identifying markers of individuality and distinction... The characters bleed into each other and become an amorphous, indistinguishable mass, not because most of them are not given names, but because they are so lacking in characterization that they are essentially the same character, re-emerging in different settings attached to different contemplations which are masquerading as a storyline...intended to draw the reader into an intractable mind maze... (pp. 145-146)

Despite his critical tone, Sibanda also comes closest to deconstructing the essence of Egblewogbe's intention and achievement in Mr. Happy. By noting the work's filiation to Armah via the nameless, faceless man, he acknowledges to a textual kinship between Mr. Happy and Ayi Kwei Armah's work. 
And by emphasizing the erosion of markers of individuality and uneven character development in Mr. Happy, Sibanda indirectly acknowledges Mr. Happy's re-inscription of the trope of broken victims with fragmented psyches cast on the margins of the postcolonial state who subversively fumble their way to an elusive integrity that is denied by the circumstances created by the postcolonial state-as-hammerer of hopes.

Dervi, the main character in the title story (and indeed, his alter egos in the other fragments of short stories that flank and flesh out the title story) has this in common with Armah's Man and Awoonor's Amaamu: he is a mentally shattered victim force-forged in the chaotic smithies of postcolonial Ghana. The settings of his life are as chaotically labyrinthine as his aimless journeys through a confusing existence that he tries to negotiate. His psyche, to the degree that he is seen to have one, is the fragmented remnants of what should have been. Dervi is a character who has been hammered by the capricious God(s) of postcolonial state power and has lost the power to engage as a normal being. His often stream-of-consciousness ramblings - reported or direct - bespeaks the inner turmoil that he experiences, and the splinters of dialogue he engages in are consistent with what we would expect from what Sibanda calls a man with "intractable mind mazes." In other words, rather than see these as elements of "incomplete" character development or incoherent, stochastic dialogues as shortcomings in Mr. Happy, it would be more useful to read them as core to the genius of the work since they reflect on a larger chaotic dynamic in the society that Egblewogbe is trying to chronicle, a reality that we also see in the work of Armah, Awoonor and the others already referred to. The randomness of dialogue and even the seemingly misplaced philosophical meditations on often disparate issues, both in the title story and the minor stories of the collection that flank it, are also consistently revealing of the mindset of the leading character whose consciousness mediates the entire collection of stories. 
A better understanding of the above may be generated by situating the work in its proper socio-cultural milieu. While a nuanced reading of the text may find parallels between it and works from other traditions beyond Ghana, that acknowledgement must at best serve as a prelude to the ultimate recognition that this is a Ghanaian work situated within a Ghanaian literary tradition that has unique cultural lineaments. The clue that Egblewogbe is rewriting a $21^{\text {st }}$ century version of the broken, mentally sequestrated wanderer that we see in earlier postcolonial Ghanaian work is given very early, in fact, in the epigraph to the collection is a meditation on an ironic liberty that paradoxically resonates more with imprisonment than freedom; a prisoner's tale experienced in a labyrinthine cell in which a persona repeats the sequence of journeys through confusing and repeated acts propped in euphemisms that belie the unbearably devastating nature of futile being. From that auspicious beginning, the collection could easily be read as a $21^{\text {st }}$ century diary of a Mersault in Albert Camus' The Stranger trying to make sense of the capricious undertow of a world that makes no sense and one in which concepts like justice and freedom are subject to all forms of capricious abuse by empowered faceless actors as hypocritical as they are prejudicial, or a Kafkaesque Gregor Samsa woken up in the new millennium to find out that he has metamorphosed into a monstrous vermin once again.

But these resonances are, at best, peripheral. The collection is anything but another instalment of what Soyinka (1976, p. viii-x) calls "the universal humanoid abstraction". Mr. Happy is firmly anchored in a Ghanaian tradition whose ancestry, in purely postcolonial terms, dates to Ayi Kwei Armah, Kofi Awoonor and others. It is, after all, the story of a man living in "Kwame Nkrumah's Ghana" who once dreamed of being happy and ends up disappointed, having his psyche split by the heavy hammer of a fate that is at once bewilderingly personal but also ubiquitous enough to be called "the National Woe" (p. 114). He is also a man who succumbs to madness as a 
result of what he suffers, and one whose madness mediates both the title story, and as I have already suggested, the other nine stories in the collection. That the entire collection may be read as fragments of one overthrown mind yielding to the variegated sores of the postcolonial state is plausible because each of these short stories display more than a strong hint of affiliation to the only well delineated character in the collection, the main character in the title story "Mr. Happy and the Hammer of God." This man, Dervi, or the Mr. Happy of the title, is a Ghanaian citizen with the university level education who lives and suffers in a Ghanaian environment. Even more specifically, he spends his life in the physical ambience of the city of Accra. We are told that he had Afro-styled hair and would look at himself in the mirror and admire this trait in the mornings. While in the school, he had friends like Bubu and Bubu's cousin who were Ghanaian and presumably city-born urbanites with eyes set on becoming successful in the professional ranks just like himself. Dervi, we are told, wanted to be a financial journalist, and read Ghanaian newspapers like The Daily Graphic with as much gusto as he would later read the pages of Newsweek and The Economist. His early morning routines include listening to his favourite music which we are told included Bruce Springsteen's Trapped, Waterloo by ABBA, the Eagles and their Tequila Sunrise; standard fare for Ghanaian urbanites in tune with the international music scene.

To add further to this realistic element, an unmistakeably Ghanaian setting is powerfully invoked as a device. Dervi's room is on the second floor of a rundown storey building "whose owners had forgotten the meaning of maintenance" (p. 60). That the apartment was in a slum-like segment of Accra is powerfully highlighted, adding to the sense of general impoverishment that Dervi and people like him endured. The narrator emphasizes for us how depressingly bad things were:

Through the dirt-rimmed window, the poor, congested neighbourhood made a brave showing. In the courtyard 
of the next house two girls were hanging out washing; barely twenty feet away from them a man urinated carelessly against the wall. Dirty buildings, rusting roofing sheets and a few gallant trees struggling against the man-made barrenness of Abossey-Okai all fought for attention in the little square of glass. (p. 59)

In addition to this, we see Dervi travel by foot across the city of Accra, clearly establishing his chequered relationship with extended spaces of poverty and the sharply contrasting affluence symbolised by corporate infrastructure of the banks and other powerful institutions in the city. As Dervi walks through recognizable landmarks in Accra such as Abossey Okai, Obetsebi Lamptey Circle, Ring Road, Kwame Nkrumah Circle, the Castle Road, Kwame Nkrumah Avenue, and Graphic Road, he also records for us the common street banter between infuriated drivers on Accra streets during the heavy traffic hour, drivers whose flirtations with road rage straddles both the comic and tragic ends of the social spectrum while they channel the tensions of living in a predictably chaotic modern African city.

Dervi's journeys through Accra also recall earlier sojourns of characters in earlier works by Ghanaian writers, emphasizing in the process the common motif of journeys-asvisual-representation of the depressing postcolonial landscape in Ghanaian literature. For instance, in Ayi Kwei Armah's The Beautyful Ones, multiple instances of similar journeys are recorded and finally climaxed with the famous trek of Koomson through a literal shithole to brief respite on the other side of postcolonial corruption. We learn to understand the journeys of the Man to and from work, for instance, setting devices that elucidate the message of postcolonial Ghanaian existence as a daily wading through scatological dump. In Fragments too, both Baako and Juana take similar journeys across both Accra and Ghana, discovering more about a landscape that stresses by both symbolic and literal illustration, the dire mess that living in Accra/Ghana encapsulates. Awoonor's Amaamu's long trek 
from Accra to the coastal boundaries of the Volta region achieve a similar purpose as the deterioration of his mental faculties coincide with the revelations of a landscape that he encounters on the way, an experience that facilitates his ultimate capitulation to ultimate despair.

If we have established Mr. Dervi's Ghanaianness by pointing to his personal attributes, his association to setting as well as his kinship with other Ghanaian characters in earlier works as instances of intertextual engagement, we ought to proceed to deconstruct Mr. Dervi's madness as well to further stress that point. Egblewogbe makes no pretensions when establishing that mad thematic element at the outset of his narrative. "Mr. Happy" opens with Dervi's screams in response to incubusinduced nightmares while the all-seeing eye of a panopticonlike intelligence watches from above, seemingly intent on implementing the sentence of torture. Dervi is a man tortured by madness whose cause is associated with metaphysical guilt but could be better explained in terms of an oppressive social order of being manifesting in the repressed unconscious that Dervi recalls in his dreams:

They were nightmares, replete with demons, Hellfire and heavily punctuated with the presence of judgmental, merciless God who seemed incapable of understanding Dervi...[The dreams] usually end with some sort of judgment scene - a figure I cannot properly describe appears and I hear a shout: "Guilty as charged!" and another voice says, "Now Dervi, depart you to Hell, prepared for the devil and his angels." (p. 69)

The language above is flowingly religious and metaphysically grandiose, but it stresses the element of trial, or a façade of the same. Fairness is not part of this trial process, and it invariably ends with condemnation and strictly implemented segregation from the society of the holy and the called. In real life, this dream sequence/nightmare manifests as a madness 
which creates a social stigma and marginalisation from normal social activity such as holding a job, or just interacting with other human beings.

Metaphysics and metaphorical flourishes aside, Dervi's mental breakdown has more immediate, worldly triggers. We are told that he was once "a brilliant, polite, and amiable" young man while he sat complacently in a system doped with ideological state apparatuses such as religion and false education that killed off true consciousness. His troubles began when he sought to embrace a rationalistic worldview and question the religiousand authoritarian order of things that scarred with chthonic monsters and offered temporary relief via Catholic rosaries and scapulars (pp. 124-125). His first major breakdown on university campus is attributed to yielding to the inimical influence of Bubu the heresiarch and her ideas about emancipating the self from religiously imposed mental slavery, but those breakdowns also coincide with his first encounters with political consciousness when he listens to political speeches and "became slave to the erudite flow of words, holding his breath with his gaze frozen" (p. 112), when he gets to know how:

Black governments maintained the repressive structures [of colonialism]; even reinforced them, creating an elitist club to replace the colonialist ones. Now, as you can see, a person's only real chance of success is to join the elite. Getting recommendation is the only way. Either you are well "connected" or you are jetsam... Flotsam." Many of our youth...starry-eyed, with good degrees, are wilting at the shock of the wicked socioeconomic regime (pp. 112-113)

Wilting at the shock of a wicked regime is exactly what happens to Dervi at the end. From a man who once aspired to talk as "one man to another and not man to madman" (p. 69), he finds himself being pushed to the margins for daring to nonconform, and denied by what he calls the ulcerous society, he chooses 
the safety of the "the dark dungeons of institutions" where he can speak either as "man to madman," or "madman to man" depending on who is labelling the interlocutors. Ultimately, that is a subversively fluid choice of roles that maps his resilience to the status quo and desire to forge a new social synthesis that would transcend the hammering chaotic present. Dervi asserts that things would eventually even out themselves because the dialectic of the postcolonial state demand that dialogues be about "man to madman occurred at the beginning of the interaction, man to man at the end..." (p. 69).

Seen that way, "Mr. Happy" can be read as a story of mental resilience, one appropriates the avatar of temporary madness to negate the dominant mood of pessimism and serve out the possibility of happy resolution sometime in the future. But that hope is meant for the long-term future, the end that is not yet. In the now, Dervi and those I have called his alter egos in this essay have to live out the full impact of a society that is out of joint and puts people's minds out of joint as well. It is a society in which, as other stories in the collection capture it, immediate to-morrows are filled with the sounds of weeping while the chance "to smoke something...ultimate" in order to escape the gory present is denied ("To-morrow," p.5); where shelters on stormy nights are filled with "noisome effluvia from nether end[s]" of nameless and yet seemingly ubiquitous tormentors who also accuse incessantly without naming their victims' crimes ("Down Wind,"p.21); where pharmaceutical interventions double as opportunities for heartless profiteers to "hand the rope callously to the willing suicide" at extra profit ("Pharmaceutical Intervention," p. 14); or where a neo-Erewhonian justice regime demands that those who are cuckolded in marital relations be shot for being victims ("Small Changes in the Dynamic," pp. 3139). In short, $M r$. Happy is anything but happy in its presentation of the Ghanaian now; it rather presents a post-happy continuum in a postcolonial universe where justice and order are chimeric and the conscious man or woman is one who finds out that he 
or she is no better than "a condemned [person] being led to the gallows" ("Twilight" 52). It presents a vista of disorder breeding disorientation in perpetuity, a world that has gone off its hinges and taken the minds of men and women with it, and ultimately, one in which, "each generation regenerates, does unto others what was done unto them and more souls are saddled with the terrible gift of life ("Twilight," p. 52).

If this vision of postcolonial Ghanaian lives sounds confusing, it is because Egblewogbe, through Dervi and the ten stories Dervi's consciousness mediates in Mr. Happy, has brought us the latest update on the still evolving narrative of the Ghanaian experience against the backdrop of perplexing socio-economic as well as political conditions. Some may disagree with unorthodox narrative techniques employed in the collection, but it may very well be that not a few readers would betray a hint of recognition while the work because they have seen men and women like Dervi who hold onto madness as a plank to survive and even subvert powerful orders of being in a challenging Ghanaian environment. As this essay has tried to show, the story has been told before, and may well be told again as life and fiction continue to reinforce each other in postcolonial Ghana. 


\section{References}

Achebe, C. (1989). The Novelist as Teacher. Hopes and Impediments. NY: Double Day. 40-46.

Aidoo, A.A. (2012). Blurb. Mr. Happy and the Hammer of God \& Other

Stories. Oxfordshire: Ayerbia Clarke Publishing Limited.

Ali, M. N. (2005). The Prophet of Zongo Street. NY: HarperCollins.

Andrade, S. Z. (2011). Adichie's Genealogies: National and Feminine

Novels. Research in African Literatures. 42(2): 91-101.

Angmor, C. (1996). Contemporary Literature in Ghana, 1911-1978: A

Critical Evaluation. Accra: Woeli Publishers.

Anyidoho, K. (2012). Blurb. Mr. Happy and the Hammer of God \& Other

Stories. Oxfordshire: Ayerbia Clarke Publishing Limited.

---. (2004). The Back Without Which There is No Front. Africa Today 50.2

---. (2000). National Identity and the Language of Metaphor. In: FonTomFrom:

Contemporary Ghanaian Literature, Theatre and Film. Ed. Kofi Anyidoho. Atlanta, GA: Rodopi.

Armah, A.A. (2006) Fragments. Popenguine: Per Ankh.

---. (1968). The Beautyful Ones Are Not Yet Born. London: Heinemann

Educational Books.

Awoonor, K. (2006). The African Predicament: Collected Essays. Accra:

Sub-Saharan Publishers.

---. (1971). This Earth, My Brother. NY: Doubleday \& Company.

Bloom, H. 1994. The Western Canon: The Books and School of the Ages.

NY: Riverhead Books. 15-39.

Booker, K. (1998). The African Novel in English. Oxford: James Currey.

Clark, Anna. 2012. Exploding the Canon: On the African Writers Series. $L A$

Review of Books. October 6. https://lareviewofbooks.org/article/

exploding-the-canon-the-african-writers-series. Retrieved 2021-0808

Clayton, J. and Rothstein, E. (1991). Figures in the Corpus: Theories of Influence and Intertextuality. In: Influence and Intertextuality in Literary History. Eds. J. Clayton and E. Rothstein. Madison, WI: The University of Wisconsin Press. 1-35.

Currey, J. (2008). Africa Writes Back: African Writers Series and the Launch of African Literature. Athens: Ohio UP.

Egblewogbe, M. (2012). Mr. Happy and the Hammer of God \& Other Stories. Oxfordshire: Ayerbia Clarke Publishing Limited.

Eliot, T.S. (2001). Tradition and the Individual Talent. The Norton Anthology of Theory and Criticism. Eds. Leitch, V.B. et al. 10881098.

Fredua-Agyeman, N. (2012). Blurb. Mr. Happy and the Hammer of God. Oxfordshire: Ayerbia Clarke Publishing Limited.

Gikandi, S. 2008. Introduction. A Grain of Wheat. Harlow: Heinemann. i-iv. 
Hartman, S. V. (2003). The Position of the Unthought. Qui Parle. 13(2): 183-201.

Irele, A. (2009). Introduction: Perspectives on the African Novel. The Cambridge Companion to the African Novel. Ed. Irele, A. Cambridge: Cambridge UP. 1-29.

Jeyifo, B. (1988). Ben Okri. In: Perspectives on Nigerian Literature, 1700 to Present. Ed. Yemi Ogunbiyi. Lagos: Guardian Books. 277-281.

Kehinde, A. (2003). Intertextuality and the Contemporary African Novel. Nordic Journal of African Studies 12 (3): 372-386.

Larbi Korang, K. (2004). Writing Ghana, Imagining Africa: Nation and African Modernity. NY: University of Rochester Press.

Mavengano, E \& Muchativugwa H.L. (2019). Kaka Country: An Intertextual Reading of National Dysfunction in Bulawayo's We Need New Names and Jinga's One Foreigner's Ordeal. Literator. (40): 1

Nsele, Z. (2020). Part III: Afropessimism and Rituals of anti-Black Violence. The Mail and the Guardian. Retrieved 2021-03-04.

Ogede, O. (2011). Intertextuality in Contemporary African Literature: Looking Forward. Lanham, MD: Lexington Books.

Ojaide. (2015). Contemporary Africa and the Politics in Literature. In: Indigeneity, Globalization and African Literature. African Histories and Modernities. NY: Palgrave Macmillan.

---. (2009). Examining Canonization in Modern African Literature. Asiatic, (3): 1. 1-20.

Selasie, T. (2005). Bye-Bye, Babar. The Lip Magazine. March 3.

Sexton, J. (2016). “Afro-Pessimism: The Unclear Word," Rhizomes: Cultural Studies in Emerging Knowledge (29): 1

Soyinka, W. (1976). Myth, Literature and the African World. Cambridge: Cambridge UP.

Sibanda, S. (2016). "Review: Mr. Happy and the Hammer of God \& Other Stories," English Academy Review. (33): 1: 145-147.

Veit-Wild, F. (2006). Writing Madness: Borderlines of the Body in African Literature. Oxford: James Currey, 2006.

Yitah, H. (2017). Foreword. After the Ceremonies: New and Selected Poems. Lincoln: University of Nebraska Press. Ix-xiii.

Zengin, M. (2016). An Introduction to Intertextuality as a Literary Theory: Definitions, Axioms and the Originators. Journal of Social of Social Sciences Institute. (50): 299-327. 